\title{
LEGAL LIABILITY IN THE CANADIAN ARCTIC RELATING TO OIL SPILLS AND BLOWOUTS
}

\author{
D. E. LEWIS, Q.C.*
}

\begin{abstract}
There is an ever-increasing concern in today's society about problems arising from pollution, but issues of liability for and prevention of pollution in the Arctic are particularly acute. This article discusses the pollution problems of the oil and gas industry in the Arctic with respect to liability for oil spills and blowouts. The article considers possible common law and statutory liability for personal injuries and property damage caused by blowouts and oil spills that may occur both on and off shore. The article concludes with a discussion of the special problems of foreseeability of damage in the Arctic.
\end{abstract}

\section{A. INTRODUCTION}

The Canadian Arctic has taken a place in our national heritage that was undreamed of a scant few years ago. If we thought of it at all, we thought of a few Indian tribes and Eskimos eking out a bare living in ways more or less unchanged for years, a few trading posts, police out-stations, one or two mining ventures and a single oilfield at Norman Wells. We recognized that there were some military bases of the Distant Early Warning system in later years, but our knowledge vas scanty.

We in the oil industry have known that the frontier of exploration was moving north and offshore; the Federal Government in the late 1950 's and early 1960's was doing all that it could to encourage exploration by establishing regulations which would attract the industry, but still industry moved slowly. The Prudhoe Bay discovery accelerated the effort and now the industry has focused a lot of its exploration effort in the Canadian Arctic, onshore and off. Nearly all the land available for permit has been filed upon. Contemporaneously with the discovery of oil in the north, the world became overly conscious of pollution and the dangers of pollution, real and unreal, upon our environment. Oil spills and blowouts have been given publicity unheard of a few years ago and legislatures everywhere are giving their attention to possible pollution of the land and the sea, and this, of course, is true of the Canadian scene.

The purpose of this paper is to examine the civil legal liability resulting from oil spills or blowouts, onshore and offshore. The theories of liability present interesting legal questions, but just how far will operators be held liable for damages is even more interesting. For instance, will we require operators to compensate trappers, or even furriers, for loss of profit or increased prices from fur-bearing animals? Will an operator be held liable because the Eskimo is compelled to travel to more distant areas, or even have to move his village to another place? Could traders sue for loss of profit when these moves are made? These questions involve policy considerations of the highest magnitude which will have to be resolved by Parliament or the responsible legislatures. In making these decisions the legislatures will have to weigh the effect upon the oil and gas industry as well as other resource in-

- Regional Counsel, Law Department, Western Region, Imperial Oil Limited, Calgary. 
dustries. Excessive or far-reaching liability or environmental control could lead to abandonment of exploration, or even production, and the loss of benefits that can be accredited to development, employment, development of towns, new industries, services and the like. This could, of course, be a staggering loss for Canadians, so the mantle is not light.

Oil spills as referred to in this paper could involve accidental spills due to tanker collision or grounding, tanker loading or unloading, accidents or breaks to pipelines onshore or off, and accidents in producing operations on drilling rigs, platforms, or onshore. Deliberate dumping of oil and water from ships or drilling operations could be another source. Blowouts can occur offshore or onshore and can result from either accidents or negligence.

The law pertaining to these matters is not clearly defined. As I will demonstrate, there is very little statute law involved, so that the common law has to be examined and applied in most cases. In as far as the problem of oil spills and blowouts involves the whole ambit of negligence and nuisance, and a large number of texts have been written on the subject, this paper only allows me to raise a number of principles for discussion. I am also ignoring any claims presently being contemplated by Indian or Eskimo groups to lands in the Arctic based upon historical or original ownership.

\section{B. COMMON LAW LIABILITY}

\section{Onshore Blowouts and Oil Spills}

(a) Liability for Personal Injuries

The principles of liability are the same as those of the common law provinces. A lessee would be liable for personal injuries caused to non-employees by the negligence of its personnel, and probably also for the negligence of an independent contractor (unless unlawfully performed) on the ground that oil drilling, producing or pipelining would be regarded as inherently dangerous and the use of a third party will not remove liability. The mere removal of paint with an inflammable substance has been held to be inherently dangerous. ${ }^{1}$

Employees in the Yukon and Northwest Territories are covered either by the Workmen's Compensation Acts of one of the Provinces (for a period not longer than a year), or by insurance, the minimum requirements of which are statutory. ${ }^{2}$ Civil liability suits are prohibited in most cases, as in the Workmen's Compensation Acts of the Western Provinces, for instance, between employer and employee, and employers and employees connected with the operation. Claims can be made in some negligence cases against employees of other employers. The Yukon Ordinance even allows a claim to be made against other employers even if under the Act for compensation purposes.

(b) Liability for Property Damage

(i) The Rule in Rylands v. Fletcher; Strict Liability

The owner or person in control of land is, subject to the Canada Oil and Gas Land Regulations and to the defence mentioned below,

\footnotetext{
${ }^{1}$ Savage v. Wilby [1954] S.C.R 376 at 380; (1954) 3 D.L.R. 204 at 206-7; wherein Kellock J. cites with approval the statement made in Salmond on Torts (11th ed.) 134. See also The Liability of a Drilling Contractor, (1966) 5 Alta. L. Rev. 108.

2 Workmen's Compensation Ordinances, Yukon and North West Territories, respectively.
} 
strictly liable regardless of fault to adjacent landowners for damage caused by the escape from his land of a dangerous substance brought there by an "abnormal" use of land. ${ }^{3}$

Drilling oil or gas wells would probably be held to be an "abnormal" use of land, notwithstanding a decision that held that a wartime munitions factory was "normal" use. ${ }^{4}$ The rule does not apply except where the substance escapes to another person's land. ${ }^{5}$ There is legal uncertainty as to whether strict liability under this head extends to personal injury as well as property damage. I would suggest that in Canada it does so extend. ${ }^{6}$

A lessee would probably claim Statutory Authorization as a good defence to an action based on strict liability under Rylands v. Fletcher. ${ }^{7}$ This defence rests on the principle that where the legislature authorizes an undertaking, such authorization often confers immunity from strict liability, but not from negligence. ${ }^{8}$ In most cases where the defence of Statutory Authorization has been raised, the legislative authorization was mandatory and not permissive, and usually the operations being carried on are for the direct benefit of the Government (e.g. a waterworks system). Nevertheless, it is suggested that this defence could extend to the drilling and producing of oil wells, since the issuing of licences and leases and the method of operation are closely regulated by the Canada Oil and Gas Land Regulations, Canada Oil and Gas Drilling Regulations or the Production and Conservation Act.9 The Government also has an interest in the land and receives benefits in the form of fees, rents and royalties. In the result, the lessee might only be liable in cases involving negligence.

However, the burden is not on the plaintiff in such a case to prove negligence; rather, the lessee, where he relies on this defence, must establish such a great degree of care that it may be said there was no other way the operation could be carried out-that is, the escape of the oil was inevitable in the circumstances, and no amount of care would have prevented it. This is a difficult burden to discharge.

(ii) Negligence

A lessee would be liable in damages caused by negligence of its servants and also of its independent contractors. ${ }^{10}$ The principle is well established that he who does not take the ordinary precautions taken by all prudent operators will be liable in damages to compensate for injuries which can reasonably be foreseen. Proof of fault on the part of the lessee is essential. In an action based on negligence, the plaintiff must affirmatively show negligence on the part of the lessee. This is a more difficult burden for a plaintiff to discharge than would be the case if he were to sue under the principle of Rylands v. Fletcher. ${ }^{11}$

3 Rylands v. Fletcher (1868) L.R.3 H.L. 330.

- Read v. Lyons \& Co. [1947] A.C. 156 (per Lords Simon and MacMillan, disapproved by Fleming on Torts 289 (2nd ed.); see also Curran, Liability for Air Pollution by Natural Gas Processing and Sulphur Recovery Plants (1966) 5 Alta. L. Rev. 14 at 22.

s Read v. J. Lyons \& Co., supra, n. 4.

- Aldridge v. Van Patten [1952] 4 D.L.R. 93 (Ont. H.C.).

7 See Bredin, Legal Liability for Water Flooding (1961) 6 Alta. L. Rev. 516 at 529.

- Northwestern Utilities v. London Guarantee Corp. [1936] A.C. 108 (Appeal from Alberta Supreme Court); J. P. Porter Co. v. Bell [1955] i D.L.R. 62 (N.S.C.A.).

9 S.O.R. 61-253, and R.S.C. 1970, c. 0-4. Contra, Tort Liability in Waterflood Operations (1966) 5 Alta. L. Rev. 52 at 64 .

10 See The Liability of a Drilling Contractor, supra, n. 1.

"Supra, n. 3. 


\section{(iii) Nuisance}

The essence of liability under this head of damage is interference with an occupier's interest in his quiet enjoyment of his land. There is probably little difference now between liability for nuisance and for negligence, since liability for both torts now appears to be based on reasonable foreseeability of damage. It would appear there is probably no longer. strict liability in nuisance. ${ }^{12}$ Even if the tort of nuisance is still to be regarded in Canada as a strict liability offence, the defence of Statutory Authority would be available to the lessee. This defence was discussed previously.

\section{(iv) Trespass}

I would suggest that there is no liability in trespass, since the movement of the oil onto another's land would not be directly caused by the act of the lessee. ${ }^{13}$

\section{Offshore Oil Spills and Blowouts}

(a) Liability for Personal Injuries

The principles are the same as for onshore blowouts.

(b) Liability for Property Damage

(i) Rylands v. Fletcher; Strict Liability

There is no liability under this rule for offshore blowouts or oil spills, because there is no land in the occupation of the lessee, a prerequisite to liability under the rule. Licence to use waters might lead to a claim under the rule on the same grounds as a sub-lessee could claim on shore.

\section{(ii) Negligence}

There would be liability for offshore blowouts in accordance with the ordinary principles of negligence. This is probably true regardless of the fact that the breach of duty and the damage occur in different places, since it is not a question of conflict of jurisdiction. ${ }^{14}$

\section{(iii) Nuisance}

An action in nuisance would probably succeed, since the gist of such an action is the damage caused and not the breach of some duty at some particular place. ${ }^{15}$

\section{(iv) Trespass}

There would be no liability in trespass for the same reasons as given above.

\section{(c) Damages}

Pecuniary damages (that is, damages for financial loss) in all the above cases would be restricted to direct loss of profits by the person whose person or property is principally injured. There is little or no liability for so-called "relational interests"; that is, there is no liability

\footnotetext{
12 The Wagon Mound (No. 2) [1966] 2 All E.R. 709 (P.C.); Goldman v. Hargrave [1966] 2 All E.R. 989 (P.C.).

13 Read v. J. Lyons \& Co., supre, n. 4.

14 Abbott-Smith v. Governors of the University of Toronto (1964) 49 M.P.R. 329 (N.S.C.A.).

is Gronlund v. Hansen (1968) 69 D.L.R. (2d) 598 (B.C. Co. Ct.).
} 
to third persons who suffer purely economic loss by reason of the direct physical injury caused to another person. ${ }^{16}$

Non-pecuniary damages, such as for direct injury to land or goods, or to the person, or loss of business profits by the person directly injured, are recoverable in accordance with the general principle of damages, viz., that the injured party is entitled to recover an amount of money that will put him in the same position, as far as possible, as he was in before his interests were injured.

\section{JURISDICTION}

\section{Onshore}

Section 146 of the B.N.A. Act, 1867, specifically contemplates the admission of the Union of Canada, Rupert's Land and the North Western Territory as well as, of course, other colonies and persons. One of the terms of union was "to grant to the Parliament of Canada authority to legislate for their future welfare and good government". ${ }^{17}$

The Government Organization Act, 1966, charges the Minister of Indian Affairs and Northern Development with the responsibility for the development of the North and for the general co-ordination of federal activities in the area. Powers have been delegated within the Yukon and the Northwest Territories under the Yukon Act and the Northwest Territories Act. These provide for executive, legislative and judicial responsibility and more or less coincide with the powers granted to a Province, with the great exception being the control of natural resources. In the result, statutes or ordinances in any area can have two sources and the effective courts are those of the Yukon or the Northwest Territories, civil and criminal. Their jurisdiction would extend to the Arctic Islands claimed by Canada.

\section{Offshore}

Jurisdiction over waters of the mainland coast and between the Arctic Islands is a little more complicated. A criminal case, ${ }^{18}$ where an Eskimo was accused of shooting a polar bear unlawfully, suggests that the Court of the Northwest Territories would accept jurisdiction on water or the ice mass off the coast. In this case the shooting took place on the sea ice several miles off the coast north west of Posley Bay, Northwest Territories. A tort founded on nuisance and committed offshore British Columbia was held to be actionable in that Province. ${ }^{19}$

A pollution claimant might also bring his action in a court having Admiralty jurisdiction, even if the damage done is onshore, above the low water mark. By the Admiralty Act, 1956, the Canadian Courts of Admiralty exercise the same jurisdiction as the English Courts of Admiralty. Now some of the limitations of the English Courts have been removed by the new Federal Court Act ${ }^{20}$ which continues the Admiralty jurisdiction. One interesting aspect of a claim in Admiralty is that an

16 Liesbasch Dredger v. The Edison S.S. [1933] A.C. 449; Seaway Hotels v. Grogg Ltd. (1959) 17 D.LR. (2d) 292 (Ont. H.C.); also discussed in remoteness of damage later.

17 Address to Her Majesty the Queen forming part of Schedule (A) to Order of Her Majesty in Council Ad mitting Rupert's Land and the North Western Territory into the Union, June 23rd, 1870 (R.S.C. 1952, Vol. VI at 624B). To remove any doubt, the B.N.A. Act, 187,34 and 35 Vict. c. 38 by 8.5 confirms it and by 8. 4 providea for government by the Parliament of Canada.

18 Regina v. Tootalik E4 321 (1970) 74 W.W.R. 740.

10 Gronlund v. Hansen, supra, n. 15.

${ }^{20}$ S.C. $1970-71$, c. 1 . 
action against a shipowner for pollution by oil may be maintained even where negligence cannot be proved, if the claimant can show that pollution was the result of an unseaworthy condition.

\section{BREACH OF STATUTORY DUTY}

The Oil and Gas Production and Conservation Act ${ }^{21}$ has powers setting up regulations concerning themselves with drilling and producing requirements, but so far none have been passed. The Government relies on those still made under the authority of the Territorial Lands Act and the Public Lands Grants Act, or procedures established by the Department of Indian Affairs and Northern Development.

I doubt that there is any civil liability as a result of a breach of these regulations. The general rule, I believe, is that a statutory provision or regulation setting down the manner of work does not create a duty the breach of which gives rise to civil liability, at least where penalties are set out in the Statute for breach of such provision.22 Even if it does create a duty, it merely imposes a duty not to be negligent and thereby involves the notion of taking care not to injure persons or property, ${ }^{23}$ but does not give rise to an action by the Government for civil liability or to an action by private individuals.

The Arctic Waters Pollution Prevention Act ${ }^{24}$ has been passed by the Parliament of Canada but has not yet been proclaimed in force. It provides that persons exploiting any natural resource and the owner of any ship that navigates within Arctic waters are liable and, in the case of the owners of the cargo of any such ship, they are jointly and severally liable up to an amount to be determined by regulations for all loss or damage resulting from the deposit of waste (which includes oil and petroleum products). The liability of the shipowner and cargo owner is absolute and does not depend upon proof of negligence. Arctic waters are defined as meaning those waters adjacent to the mainland and islands of the Canadian Arctic within the area enclosed by the sixtieth parallel of north latitude, the one hundred and forty-first meridian of longitude and a line measured seaward from the nearest Canadian land a distance of one hundred nautical miles. The Act also provides for the establishment of shipping safety control zones and enables the Governor in Council to make regulations relating to navigation in these zones. Draft regulations have been submitted to the shipping and oil industries for their comments. It could be that polluted waters flowing into the Arctic Ocean would be covered by the Act.

An Act to Amend the Canada Shipping Act ${ }^{25}$ applies to all Canadian territorial waters south of the sixtieth parallel of north latitude and to all Canadian territorial waters north of the sixtieth parallel of north latitude that are not within a shipping safety control zone prescribed pursuant to the Arctic Waters Pollution Prevention Act. This Act provides that the owner of a ship that carries a pollutant in bulk and the owner of such cargo are jointly and severally liable for all loss and damage caused by the discharge of a pollutant from a ship in waters

\footnotetext{
21 R.S.C. 1970 , c. $0-4$

2 Commerford et al v. Board of School Commissioners for Halifax et al. [1950] 2 D.L.R. 207 (N.S.S.C.).

${ }^{23}$ Lochgelly Iron \& Coal Co. v. McMullin [1934] A.C. 1.

24 S.C. 1969-70, c. 23; R.S.C. 1970, (1st Supp.), c. 1.

25 S.C. 1969-70, c. 35; R.S.C. 1970, (18t Supp.), c. 38.
} 
to which the Act applies. By definition "pollutant" includes oil and any substance that is prescribed by the Governor in Council to be a pollutant. In the absence of actual fault or privity on the part of the shipowner or cargo owner, such liability is limited to the lesser of $\$ 134$ for each ton of the ship's tonnage and $\$ 14,000,000$. Where the total claims exceed these limitations, the amount of the excess is recoverable from the Maritime Pollution Claims Fund, which is a fund created by the levy of up to 154 per ton on oil shipments entering Canada and on all movements of oil by water within Canada.

Northern inland waters are protected by the Northern Inland Waters Act ${ }^{26}$ which is intended to accomplish in the Yukon and Northwest Territories what the Canada Water $\mathrm{Act}^{27}$ does nationally, primarily to conserve water, but no civil liability ensues for breach. Land-Use Regulations have been reviewed by the oil industry. These regulate almost every facet of drilling and production as they involve surface uses, but again would not give rise to civil liability.

\section{E. FORESEEABILITY}

This can be most difficult to predict. Lord Atkin stated the general rule thus:28 "You must take reasonable care to avoid acts or omissions which you can reasonably foresee would be likely to injure your neighbour." This statement has been repeated many times and has application in principle if not directly in tort. The Wagon Mound (No. 1) ${ }^{29}$ was an attempt to establish a guideline for setting the limits of liability for a negligent act, as the Court felt the Polemis principle ${ }^{30}$ confusing. In this case the Defendants were the charterers of the ship "The Wagon Mound". Owing to carelessness of its engineers, bunker fuel in quantity was spilled in Sydney Harbour. The oil drifted to the Plaintiffs' wharf, where repair work was being carried on by welding the Plaintiffs' ship. The manager of the wharf was alarmed and shut down the repairs, but upon assurance that welding was safe proceeded with the repairs. A fire started and destroyed both the wharf and the ship. An action was raised on the grounds of negligence against the charterers. The Courts held as the fire was not foreseeable no damages could be founded on it. The principle established by the case was that a person who is negligent is liable only for those damages which he could or ought reasonably to have foreseen and ought reasonably to have guarded against, because this is the extent of his negligence.

A second case $^{31}$ ensued when the owners of the vessels undergoing repairs sued for damages in negligence and nuisance. The Plaintiffs were successful. The evidence upon the foreseeability issue differed in the two cases, and in the second the Courts held that the Defendants should have reasonably foreseen the possibility. The judgment establishes that the injury must be foreseeable. Foresight by itself is not enough to create liability, but the greater the magnitude of the possible

\footnotetext{
20 S.C. 1969.70 , c. 66; R.S.C. 1970, (1st Supp.), c. 28.

${ }^{27}$ S.C. 1969-70, c. 52; R.S.C. 1970, (1st Supp.), c. 5.

2s Donaghue v. Stevenson [1932] A.C. 562 at 580.

29 [1961] A.C. 338.

30 Re Polemis [1921] 3 K.B. 560.

31 The Wagon Mound (No. 2) [1967] 1 A.C. 617.
} 
injury the greater the care must be to guard against it and, in nuisance, fault generally involves foreseeability. Therefore the same rules concerning foreseeability are applicable both to negligence and to nuisance. ${ }^{32}$ The judgment has been criticized in Canada ${ }^{33}$ and the suggestion made that it might not be followed here. Recent English cases are discussed in the Law Quarterly Review ${ }^{34}$ on the question of foreseeability and are of interest. In one, ${ }^{35}$ the Courts held the Defendants who had allowed a dangerous foot and mouth disease virus to escape from their premises would be liable for infection of cattle in the neighbourhood as this was a "foreseeable fact", but that they were not liable for financial loss incurred by the traders in the cattle market when this had to be closed, as they owned no property which was directly injured.

In a second case, ${ }^{36}$ the Defendants had negligently knocked over a water hydrant, with the result that water had to be cut off from the Plaintiffs' factory on an industrial estate, which suffered financial loss. The Court decided in favour of the Defendants, as the Plaintiffs' loss was too remote.

The third case of interest involved the Defendants, building contractors who were employed by third parties to rebuild a boundary wall on land adjoining a road which led to the Plaintiffs' factory. In the course of their work they damaged a cable which carried power to a factory and it could not operate for seven and one-half hours. In the result, damage was done to machinery, as molten material in the machinery solidified and caused permanent damage. The Court distinguished the first two cases on foreseeability and held the Defendants liable on the grounds that the Defendants who cut the cable could reasonably foresee the factory operation in the area would come to a halt if the power were cut. The claim was confined to that loss of profit which was consequential, not simply to the power cut but as the result of damage to the machinery. The decision was affirmed on appeal. ${ }^{37}$

All the judges held that on the facts the Defendants were liable in law for the physical damage to the Plaintiffs' property and for the loss of production and profit that it entailed. Lord Denning M.R. said:38

It is well settled that when a defendant by his negligence causes physical damage to the person or property of the plaintiff, in such circumstances that the plaintiff is entitled to compensation for the physical damage, then he can claim, in addition, for economic loss consequent on it. Thus a plaintiff who suffers personal injuries recovers his loss of earnings: and a shipowner, whose ship is sunk or damaged, recovers for his loss of freight.

In the Law Quarterly review of the case, the editor points out the conclusion might lead to some surprising results if no limitation were placed on the indirect consequences for which a tortfeasor was held liable, especially if this indirect consequence were an economic loss caused by a loss of earnings due to a fall in production. The conflict between pure logic on the one hand and practical reasons and commonsense on the other is a difficult one.

\footnotetext{
32 See discussion 82 L.Q.R. 445 and 83 L.Q.R. 13.

3s Cote. Is the Wagon Mound Good Law in Canada? (1969) 47 Can. Bar Rev. 292.

34 86 LQ.R 454.

3s Weller \& Co. v. Foot and Mouth Disease Research Institute [1966] I Q.B. 569.

so Electrachrome Ltd. v. Welsh Plastics Ltd. [1968] 2 All E.R. 205.

${ }^{37}$ S.C.M. (U.K.) Ltd. v. W. J. Whittal \& Sons Ltd. [1970] 3 W.L.R. 694; [1970] 3 All E.R. 245; also discussed in 87 L.Q.R. 8 and 34 Mod. L. Rev. 323 and 399.

39 [1970] 3 W.L.R. 697 .
} 
In the result, I can see liability to persons directly affected by oil spills or blowouts, but to those who have no property actually injured I see little hope. This would exclude Eskimos and trappers from claiming for loss of game or for having to move to more plentiful areas.

The remedies of nuisance, trespass and negligence have limitations. ${ }^{39}$ Esso Petroleum Co. Ltd. v. Southport Corporation ${ }^{40}$ was a case in point which I believe has not been altered by subsequent law. In that case an oil tanker stranded in a river estuary jettisoned an oil cargo to protect the ship. The tide carried the oil to the foreshore, where it caused damage. The foreshore owners brought an action based on trespass, nuisance and negligence, to no avail. The Court held there was no negligence. The House of Lords agreed that negligence is a necessary element of an action in trespass in the context under consideration. The case might have been differently decided had the Plaintiffs pleaded damage as the result of an unseaworthy condition.

This aspect of the law may not have too much practical bearing in the North, due to the fact the Crown owns nearly all the land and has only leased small areas, the small population in the North, and the few industries, farming or trapping enterprises there. However, it could have greater import as the North develops and must be given due consideration by all groups or companies operating in the North.

\section{F. RESERVOIR DAMAGE}

There are no Canadian cases to assist in the resolving of this issue. The principles involved deal with the fundamental theories of ownership of oil or gas, which of themselves are unresolved. Canadian courts have never determined the ownership of oil or gas underground. ${ }^{41}$ Canadian cases deal mostly with the rights of a lessee, which rights come under the general rules evolving from profit $\grave{a}$ prendre. Based on hard mineral cases, I favour the position that if the drilling was done in an orderly, workmanlike manner liability would not ensue.

The only actual blowout of any magnitude in Canada was the Atlantic No. 3 oil well disaster in 1949, when a virtual lake of oil covered a large area near Leduc, Alberta. This was settled by an Act of the Provincial Legislature. ${ }^{42}$ It is reasonable to assume similar legislation would be recommended and probably be enacted, as it appears the most practical solution. It would lead to a lot more adverse publicity than that experienced in 1949 , due to the environmental concerns today.

\section{G. CONCLUSION}

In most cases it would appear a lessee, both onshore and offshore, would be liable for damages caused by the escape of oil or gas due to an oil spill or blowout, at the suit of a person injured (Workmen's Compensation excepted) and likewise a person whose property is damaged. Liability depends upon negligence, nuisance or the rule in Rylands v. Fletcher, whether of the lessee or his contractor.

\footnotetext{
39 See also Fridman Tresspass or Negligence? (1971) 9 Alta. L. Rev. 250.

10 [1956] A.C. 218, [1955] 3 All E.R. 864 (H.L.); for discussion see Dunn \& Hargrave, Oil Pollution Problems on the Pacific Coast (1971) 6 U.B.C. L. Rev. 136 at 142-143.

"See Lewis \& Thompson, Canadian Oil and Gas, Vol. 1, 34, ref. 31A.

12 S.A. 1949, c. 17.
} 
Water pollution liability will be covered by statute. Where oil pollution injures land owned by the person bringing suit, it is actionable. Reservoir damage is still a question to be determined. If evidence of negligence is undisputed it could well end in a successful suit and could be brought notwithstanding compliance with conservation regulations. 